Abstracta Iranica

Revue bibliographique pour le domaine irano-aryen

Volume 26 | 2005

Comptes rendus des publications de 2003

\title{
« Helmet: i. In Pre-Islamic Iran ». EIr 12, fasc. 2, (2003), pp. 176-180.
}

\section{Aurélie Daems}

\section{(2) OpenEdition}

1 Journals

\section{Édition électronique}

URL : http://journals.openedition.org/abstractairanica/3359

DOI : 10.4000/abstractairanica.3359

ISSN : 1961-960X

Éditeur :

CNRS (UMR 7528 Mondes iraniens et indiens), Éditions de l'IFRI

Édition imprimée

Date de publication : 15 mai 2005

ISSN : 0240-8910

\section{Référence électronique}

Aurélie Daems, « « Helmet: i. In Pre-Islamic Iran ». Elr 12, fasc. 2, (2003), pp. 176-180. », Abstracta Iranica [En ligne], Volume 26 | 2005, document 118, mis en ligne le 08 décembre 2005, consulté le 25 septembre 2020. URL : http://journals.openedition.org/abstractairanica/3359 ; DOI : https://doi.org/ 10.4000/abstractairanica.3359

Ce document a été généré automatiquement le 25 septembre 2020.

Tous droits réservés 


\section{« Helmet: i. In Pre-Islamic Iran ». EIr 12, fasc. 2, (2003), pp. 176-180.}

\section{Aurélie Daems}

Already in the second millennium $\mathrm{BC}$, helmets were used to protect individuals during military exercise and confrontations. Several synonyms for the helmet are known from the Avesta, differing from the function it had. They are seldom found within excavations. The information we have mostly derives from secondary sources such as depictions on coins, reliefs or vases. The limited amount of depictions and finds does not permit to go into much detail. Although the sample is small, a useful typology has been proposed.

\section{INDEX}

Thèmes : 3.2.2. Pré-Achéménides et Achéménides

\section{AUTEURS}

\section{AURÉLIE DAEMS}

Université de Gent 